\title{
IAMJ
}

INTERNATIONAL

AYURVEDIC

MEDICAL JOURNAL

\section{POTENTIAL ROLE OF ACINULL-P IN MANAGEMENT OF AJIRNA W.S.R TO INDIGESTION}

\section{Rajeev Verma ${ }^{1}$, Meenakshi Verma ${ }^{2}$, M.R Pandya ${ }^{3}$}

${ }^{1}$ PG Scholar Department of RS\&BK Parul institute of Ayurevda, Vadodara, Gujarat-391760., India

${ }^{2}$ Assistant Professor, Department of Kayachikitsa, R.K Ayurvedic College and Hospital Ajamgarh, Uttar Pradesh, India

${ }^{3}$ Professor and HOD Department Of RS\&BK Parul Institute of Ayurevda Vadodara Gujarat-391760., India

Corresponding Author: meenvermabams@gmail.com

\section{https://doi.org/10.46607/iamj1708112020}

(Published online: November 2020)

Open Access

(C) International Ayurvedic Medical Journal, India 2020

Article Received: 17/10/2020 - Peer Reviewed: 08/11/2020 - Accepted for Publication: 11/11/2020

\section{(A) Check for updates}

\begin{abstract}
Ayurveda is the old traditional science deals with the management and prevention of diseases. Most of the diseases arise due to hypo functioning of Agni (bio-digestive power) and it is the root cause for the development of many diseases. Ayu (long life), Bala (strength) and Varna (complexion) etc. dependent on status of Agni. Agni present in the Jathara (Stomach and Intestine) which digest and metabolize the food and assist in growth of body hence it is termed as BhagawanIshvara-almighty God-himself. All the diseases arise as a result of less, excessive and irregular digestion of food known as Mandagni, Tikshnagni or Vishamagni respectively. Agni may get disturbed by erratic lifestyle and abnormal dietetic regimen. Disturbed functions of Agni cause indigestion of food is termed as Ajirna (indigestion). Ajirna is the most important source of production of Ama and favors genesis diseases. Avoidance of the etiological factor is the initial action in the management. Inappropriate lifestyle, unreliable seasonal regimen adherence, mental disturbance and stress may contribution in the progress of Ajirna condition. So, the Deepan, Pachan, Laghan are the basic management in Ajirna along with internal Medicine.
\end{abstract}


Acinull-P which contain Trikatu, Ajmoda, Chitrakadimoola chhal, Nausadara, Swetajeeraka, Chhoti Harad, Krishna jeeraka, works on Ajirna.

Keywords: Agni, Ajirna, Ama, Amajirna, Vidagdhajirna, Vistabdhjirna

\section{INTRODUCTION}

Ajirna is the state of incomplete process of digestion of ingested food. The main reason for indigestion is the deranged functions of Agni. Incomplete digestion and metabolism due to disturbed digestive fire leads to formation of under processed state of food termed as Ajirna. Persons who eat food in excessive quantities recklessly like cattle become prone for the development of Ajirna which may lead development of many diseases.

\section{Concept of Agni}

Agni in common language, means fire. However, in the context of functioning of living organism, which maintains its integrity and performs its vital activities, by converting-in Pakadi Karmas or biophysical and biochemical processes - the foods consumed in various ways- licked, masticated, drunk etc., not only into its various structure and functional constituents but also to provide the energy, necessary for proceeding with its innumerable vital activities. In these sequences, the term Agni comprehends various factors which participate in and direct the course of digestion and metabolism, in a living organism. Hence it is termed as bio digestive fire. Vata (Prana, Apana, Samana and Udana) augments the digestive fire. Power of Agni or normal condition of Agni is responsible for strength, health, longevity and vital breath. Food substances undergo metabolic transformation by the effect of Jatharagni, Bhutagni and Dhatvagni. Jatharagni is the main principle substance responsible for disease and health. During its normalcy it is responsible for longevity, complexion, strength, health, enthusiasm, well built, lustre, immunity (Ojas). Jatharagni is the chief among all types of Agni's because functions of Bhutagni and Dhatvagni depend on this.

Aggravation or diminution of Jatharagni results in aggravation or diminution of Bhutagni and Dhatvagni. Therefore, by all means one has to protect Jatharagni by consuming suitable wholesome dietetics and be- havior because longevity and strength depends on normal state of $A$ gni.

\section{Types of $\boldsymbol{A g n i}$}

Three main types of Agni have been described in Ayurveda namely Jatharagni / Pachakagni, Bhutagni and Dhatvagni.

A. Status of Jatharagni according to Dosha: Different functional states of Jatharagni are produced due to influence of Doshas.

i. Mandagni: Due to influence of Kapha causing Amajirna.

ii. Tikshnagni: Due to influence of Pitta causing Vidagdhajirna.

iii. Vishamagni: Due to influence of Vata causing Vishtabdhajirna.

iv. Samagni: Equilibrium state of Dosha.

Except Samagni remaining three types of Agniis causes development of diseases. Vatika disorders arise from Vishama Agni; Pittaja disorders arise from Tikshnagni and Kaphaja disorders arise from the Mandagni.

Role of Agni in the genesis of diseases: Healthy state of body and diseased condition is entirely dependent on Agni. Simultaneous and continuous circulation of Rasadhatu takes place all over the body by the help of Vyanavata. If any abnormality evolved in the Rasavaha Srotas (channels carrying Rasa) as a result disease manifest like cloud in the sky brings rain. In the same way abnormality in Dosha manifest diseases. Dosha (body humors) get aggravated by the disturbed functions of Agni. That's why life span, health, strength.

\section{Aetiology of Ajirna}

If a person afflicted with

i. Atyambupana(Drinking large quantity of water)

ii. Vishmashana (Taking food either in large or small in quantity and at unusual times)

iii. Sandharana (Suppression of natural urges) 
iv. Swapnaviparyaya (Loss of sleep at nights or sleeping during day)

v. Irshya (Envy)vi. Bhaya (Panic)

vi. Krodha (Annoyance)

vii. Lubdhane (Voracious)

viii.Rug dainya (Suffering from disease)

ix. Pradeshayuktane cha Sevyamanamannam (Taking food with jealousy) [13], Chinta

\section{Samrapti or pathogenesis of Ajirna}

Due to above aetiological factors Agni becomes greatly vitiated and fails to complete the process of digestion in sequence leading to formation of undigested food substances causes sourness and which becomes toxic in nature and initiates pathologic process inside the gastrointestinal tract and produces many diseases. Such patients do not digest the food even though consumed at proper time, quantity, wholesome diet and easily digestible food substances.

\section{Lakshana (Symptoms) of Ajirna}

The general signs and symptoms of Ajirna are abdominal distension, general malaise, headache, fainting, giddiness, stiffness in back and waist, yawing, bodyache fever vomiting tenesmus, anorexia and indigestion.

\section{Types of Ajirna}

According to predominance of vitiated doshasajirna is broadly classified into three categories

i. Amajirna: Due to vitiation of Kaphadosha.

ii. Vidagdhajirna: Due to vitiation of Pitta dosha.

iii. Vishtabdhajirna: Due to vitiation of Vatadosha.

iv. Rasasheshajirna- Related to Ahara Rasa indigestion on nutrient of food

v. Dinapaki-Ajirna - In which the food is digested on next day but cause no difficulty

vi. PrativasaraAjirna- Which is found every day normally, immediately

\section{Specific sign and symptoms of Various types of} Ajirna

a. Amajirna: Amajirna is characterized by heaviness of the abdomen or of the whole body, nausea, swelling of the cheeks and eyes, belching and similar to those occurring soon after meals signify occurrence of Amajirna. b. Vidagdhajirna: Vidagdhajirna is characterized by giddiness, thirst, fainting, sour and hot belching, excessive perspiration and burning sensation inside the body.

c. Vishtabdhajirna: Vishtabdhajirna is characterized by pricking pain in the abdomen, long stasis, tympanitis, and non-movement of flatus, obstruction of stool, delusion and general malaise.

d. Rasheshajirna: Rasheshajirna is characterized by aversion to food pure the belching and heaviness.

\section{Complications}

If Ajirna is not managed properly leading to development of Fatal signs i.e. fainting, delirium, vomiting, exercise salivation, debility, giddiness and death.

\section{DISCUSSION}

Food has been given a very significant place in individual's lives because it is primary requirement of body. It is a basic need being the source of mental and physical energy. The food that is eaten, not only effects body and the efficiency of mind but directly effects nature and habits also. The carbohydrates, starches and compound sugars are converted into glucose or dextrose when they are ready to be absorbed as a part of the blood. The fats are broken down into glycerin and fatty acids, in which forms they pass through specialized villi into the lymph. The circulatory system, made up of blood vessels and lymphatics, carries the absorbed food materials into the important stations that come next. The liver receives all the nutrients from the blood except the fats, which enter directly from the intestines into the lymph stream. As the absorbed nutrients enter the circulation, the liver plays a great role in further chemicalizing the protein and carbohydrate products. The colon or large intestine plays the next important role in the alimentation of foods. The residues which cannot be absorbed through the villi move on into the colon, where a certain amount of absorption of moisture takes place, leaving a variable solid or semi-solid fecal mass for excretion. Atyambupana (drinking too much of water) Ayurveda also teaches the importance of maintaining a strong digestive fire. The easiest way to put out a fire is to pour water on it; therefore, the digestive fire will 
also be diminished when drinking too much water or beverage. There is no quicker way to upset proper digestion than to regularly introduce copious amounts of water into the stomach. The natural digestive enzyme secretions in the stomach and small intestine are affected in such a way so as to diminish their potency. That is because the proper digestion and assimilation of food is the single greatest determinant of health. Again, according to Ayurveda, the vast majority of medical conditions find their source in the creation of Ama. Ama is the "toxic by product generated due to improper or incomplete digestion." Drinking too much fluid with the meal is therefore never recommended. The long-term practice of drinking 8 glasses of water per day will inevitably create more Ama in the system for these reasons. If this waste product is not systematically removed by the body's primary detoxification pathway various health condition will eventually arises.

\section{Vishamashana (intake of food in inadequate quan- tity and improper time)}

One should not take food before or after the appropriate time or don't consume less or more quantity without considering the nature of food substances. Taking food before the digestion of the previous meal, the digestive product of previous meal that is immature Rasa gets mixed up with the products of food taken afterwards, brings the provocation of all the Doshas instantaneously and body may suffer from many disorders or diseases. On the other hand if food is taken after digestion of the previous meal, Doshas remain in their proper places and Agni is provoked, there is proper appetite, the entrances of the channels of circulation remain properly open, eructation is purified, unimpaired cardiac function, proper passing of flatus and proper manifestation of the urges for urine and stool, product of food does not vitiate the body elements and promotes longevity in its entirely. So, food should be taken after digestion of previous meal. Taking food after time of hunger, digestive fire is disturbed by Vata, taken food is digested with difficulty and reduces loss of appetite. Food in deficient quantity produces discontent and reduces strength while that in excessive quantity causes lassitude, heaviness, gur- gling sound and malaise. Proper digestion requires good food, proper eating habits, enough digestive enzymes and other favorable conditions in the intestines. Causes for putrefaction include eating too much protein at one time, insufficient chewing, bad food combination and deficiencies of digestive enzyme.

\section{Sandharana (suppression of natural urges)}

Suppression of natural urges plays an important role in the causation of Ama. Most of the not following the Dinacharya (daily regimen) and Ritucharya (seasonal regimen) as described in Ayurvedic Samhitas for the maintenance of health. One should excrete body waste from time to time to regain healthy status otherwise it causes many troubles and if is persist for longer duration leading to development of the diseases. Vegasandharana in the sense, Malavega Sandharana (i.e. holding the reflexes of defecation and micturition) viz. accumulation of Malas (waste products) for longer periods in its Sthanas causing Amavisha (toxic substance) as a result it brings abnormal reactions and favors development of diseases. This ultimately leads to vitiation of Apanavata which vitiates Samanavata leading to vitiation of digestive power and this vitiated digestive power cannot digest even light diet also. Almost diseases manifest due to suppression of natural urges. Further vitiation of Agni i.e. Mandagni which favors the development of Ama. The role of Vegasandharana in triggering the Doshas and its influence on Agni is well described by Acharya Chara$k a$ in SiddhaSthan in relation to Sadaaturas (always suffered from disease) due to suppression of natural urges.

Irshya, Bhaya, Krodha, Lubdhane, Chinta, Shoka, Dukh and Pradeshayuktane cha sevyamanamannam

Digestive issues are a prominent part of living with anxiety. In fact, it can be so normal that many people don't even realize that anxiety is affecting the way they digest food. Stress tends to affect the normal functions of digestive system. The large intestine is particularly sensitive to stress, which tends to slow or even stop its activity and it is a major cause of constipation. Hydrochloric acid secretion may be completely inhibited by stress, emotion, or worry. It is the lowgrade, long-term, emotionally oriented life stress is the 
main culprit. Intense stress is associated more with HCL over (hyper) secretion and peptic ulcer disease (at least initially). As the stress continues, the body is exhausted and HCL production is no longer adequate. The changes that affect digestion don't start in stomach. They actually start in brain. The human brain has a limited amount of resources. During anxiety there is an activation of the "fight or flight" response, which is designed to make it easier to escape danger. The fight or flight response takes up a lot of brain's resources, so to compensate it slows down parts of brain that aren't as necessary, such as the muscles involved in digestion. The mechanism of inhibition with emotions would seem to be stimulation of the sympathetic nervous system on one hand and a reflex increase in the secretion of adrenaline have an inhibiting effect on gastric secretions leading to Mandagni condition. Neurohormonal mechanism responsible for the secretion of digestive juices, enzymes, and regulation of general metabolism is under influence of psychological factors vice versa (Sharirika Manasika Paraspara Sambandha), hence Manasikamandyata reflects in Agnimandyatain turn on Amotpatti. Similarly, the same neurotransmitters in brain that are altered and affect mood, like serotonin, also play a role in sending signals to the gut. While low serotonin can cause anxiety, anxiety can also cause low serotonin, and that means that some of the messengers that are normally travelling into body are possibly being created at a lower rate, leading to digestion issues. Another issue relates to adrenaline. During the fight or flight re- sponse, body creates massive amounts of adrenaline to give body extra energy. While adrenaline does this, body starts essentially processing nutrients at rates that aren't ideal. It changes how body processes nutrients as well and could conceivably affect digestive health].

\section{Rug Dainya (Suffering from disease)}

Having enough HCL (hydrochloric acid or stomach acid) is critical for good digestion and immune health. Without adequate HCL food is incompletely digested and failure of assimilation occurs. Impaired health may also reduce the production of many chemicals in the intestinal tract that protect it from invaders or bacteria that should not be there and are harmful. Chronic illness causes the less secretion of HCL resulting ajirna.

Shayyaprajagare, Swapnaviparyaya: Digestion, absorption and assimilation of food are a process that requires a great deal of energy. Adequate rest associated with full sleep ensures that digestive organs have time for rest and repair. Lack of sleep also makes more susceptible to stresses, which can significantly influence digestive symptoms. Studies also have shown that many patients with irritable bowel syndrome and "sensitive stomach" experience increases symptoms the morning after a restless night.

Treatment: Acinull-P contain Maricha, Sunthi, Pippali, Chhoti Haritaki, Chitrakamoola Bark Ajmoda, Sweta Jeerak, Krishna Jirak, Suddha Hingu and Nausadara,

\section{Dose-}

\begin{tabular}{|l|l|l|l|l|}
\hline Sr.no. & Name of drug & Dose & Time of administration & Anupana \\
\hline 1. & Acinull-P & $5 \mathrm{gm}$ & After food & Warm water \\
\hline
\end{tabular}

Probable mode of action of Shula: Ginger inhibits both acetylcholine-evoked and electrically induced smooth muscles contraction. Spasmolytic property is attributed to the active chemical constituent in Ginger, gingerol, which also inhibit the biosynthesis of prostaglandins. Ginger is also an anti-inflammatory drug that helps in the management of pain and discomfort associated with inflammatory changes in the gastroin- testinal tract. Zingiber officinale is proven to be efficacious in inhibiting the gastric and intestinal motility in vitro. In traditional system of medicine as well as Krishna Jeerak seeds are predominantly considered and used in treatment of mild digestive disorders diarrhea, dyspepsia, flatulence, morning sickness, colic dyspeptic, headache and bloating and acid to promote the accumulation of other herb and to improve liver 
function and a set to promote the simulation of other her and improve the liver function, cumin also has carminative stimulant and analgesic effect. It exhibits neuro tropic, antispasmodic activity. Curam Curvi seed extract is ulcerogenic and antispasmodic in experimental model. The antispasmodic effect of an alcoholic extract of caraway has shown inhibitory effect on smooth muscle contraction induced by the spasmogens and acetylcholine and histamine. Extracts from caraway produced dose-dependent anti ulcerogenic effect against indomethacin induced gastric ulcer.

\section{Mode of action drugs}

1-Maricha: It improve the function of the digestion tract, help in digestion and alleviates symptoms of indigestion, faltulance, constipation, dysentery, skin disorder, disorder of the live, Oliguria, common cold, cough, asthma. dental and vision problems.

2-Sunthi: Sunthi due to its Katu Rasa and Usnaveerya property increase the Agni (digestive fire) thereby relieves Mandagni (low fire). Sunthi is known to stimulates digestive beneficially. Sunth is described as Ruchyam that means which brings taste to the mouth due to strong katu property ginger purifies the tongue and throat thus, relieves Arochaka (anorexia).it helps in alleviating Vatakapha and Pitta. Sunthichurna. due to its Katu Rasa and Agnidipakara Karma does the Agnidipana and due to Katu Rasa and Tikshanaguna does the Pachana of Amadosha due to Katu Rasa and Laghutikshanaguna its cause Srotoshodhana. This renders the indigestion and Pakva-Apkva food into the assimilation form normal leading to the Vyadhi shaman i.e. subsidence of disease

3-Haritaki: Various extracts prepared from the powdered fruits have been wide antibacterial and antifungal spectrum (Inamdar et al, 1959). Various extracts have shown cardio tonic activity when tested on normal as well as hypo dynamic isolated frog hearts. The extracts increased the force of contraction and cardiac output without altering the heart rate (Reddy et al, 1990).

4- SuddhaHingu: This is one of the well-known Herb for the digestion and relieves the gases produced during the digestion process. Hingu by its Katu Rasa,
KatuVipaka, Tikshanaguna, UshnaVeerya increase Pitta Dosha. Increases Pitta Doshafavours Anulomana of Vatadosha. Due to its Ushnaguna it subsides pain. This is the reason why Hingu is perfect, when Anaha and Shula are the chief complaints. Hingu significantly reduces the gastric volume total acidity, free and increases the $\mathrm{pH}$ of gastric juice.

5- Pippali: Pippali is increases Agni by its Deepan action. It acts on the biliary system by secreting digestive enzyme. Thus, helps in digestive process. It normalizes the Vishamagni (improper digestion) which in turn increases Dhatu Bala (immune system). It also acts as a good Srotoshodhka. According to Sushruta, one-year old Pippali should be used for achieving its Srotoshodhaka action. By its Srotoshodhaka \& Rasayan property nourishment of Rasadidhatu take places. This is the reason for consideration of Pippali as best remedy for Pleeharoga. Preparing present in $\mathrm{Pi}$ pali shows hepatoprotective activity against tert-butyl hydra peroxide and carbon tetrachloride induced hepatotoxicity significant anti-ulcer activity. It caused a significant increase in mucin secretion and mucosal glycoprotein and significant reduction in cell shading including anti ulcer effect. It acts as a catalyst in has the action of other herbs in particular function as bioavailability enhancer by improving gastrointestinal absorption and including thrombogenesis. Thromogenesis the heat energy associated with the digestion of the food involving autonomic nervous system that controls the digestive and exhaustive process of gastrointestinal tract also shows and ti and immune stimulatory effect on giardiasis.

6- Ajmoda: Ajmoda act as Vatanulomana and help in relieving the excessive of gases generated during the digestion process so it also has the fullness of stomach. It in the hyperactivity of the central nervous system in my it also exhibits activity between against antamoeba histolytica. Pharmacological study of the oil shows its parasympathomimetic effect.

7-Jeerak: Jeera (Cumin) modulates the secretion of acid in the stomach, improves appetite and reduces gas formation. It provides strength to the stomach, intestine and liver, On the other hand due to its katu rasa and Ushnavirya increases it the Agni. By this it 
helps in increasing the appetite in Agnimandya due to the effect of Guna liquefaction of the Kapha takes place. It forces the Samanvayu in downward movement.

8- Naushadara: It is an alkaline preparation which is used in Shoola, Anaha, Adhyamana and resolvent so it is used to remove obstruction in the passages and in colic pain.

\section{CONCLUSION}

Deranged functions of Agni lead to indigestion of food are known as Ajirna (indigestion). Ajirna is the primary source of production of Ama which is the cause of almost diseases. So, all the Acharyas have described Ajirna in detail including its etiology, symptoms, fatal sign, and treatment also. Avoidance of the etiological factor is the preliminary step in any disease management. Improper lifestyle, erratic seasonal regimen, mental disturbance and related to other diseases may contribute to the development of Ajirna.

The rising use herbal drug by human is forcing is the driving force to evaluate the health claim of these agents and to develop standards of quality. Purity, safety efficacy of the drug. Indigestion is commonly encountered syndrome in medical practice. Being a multifactorial syndrome complex, many complex modes of action have been studied. Gaseous distension of the abdomen, a feeling of fullness will be relieved by the ingestion of ACINULL-P this critical analysis was to evaluate the mode of action in mentioned clinical conditions for ACINULL-P. This study observed the ingredients present in ACINULL-P a significant symptomatic relief from Agnimandya (Indigestion) Shula (Abdomen pain), Gulma (abdominal bloating). Clinically ACINULL-P is not a drug of choice, for Vata Roga (kosthagata/Amasayagata vata), but as it helps in Vatanulomana it may be effective medication as an adjuvant with some other potent medicament in the management of the disease. So, the ACINALL-P shows excellent result in this condition by this medicine all the symptoms of Ajirna get subsided in many patients.

\section{REFERENCES}

1. http://www.ayurvedalive.in/ajirna-indigestion

2. Yadunandan Upadhaya (2013) Agnimandh Nidanam 6/14. Madhava Nidana. Chaukambha Prakshan, Varanasi, India, pp. 230.

3. Yadunandan Upadhaya (2013) Agnimandh Nidanam 6/5-6. Madhava Nidana. ChaukambhaPrakshan, Varanasi, India, pp. 227.

4. Saini Neera, Byadgi PS (2013) Scientific Clinical evaluation of Ama in Amavata. MD. Thesis. Banaras Hindu University, Varanasi, India, P. 6-11

5. Byadgi PS (2011) An insight into the understanding of agni and its clinical importance. IJAR, 2(6):1637-1641.

6. Ambika Dutt Shastri (2007) Susruta Samhita, Aturopkraminiyadhaya 35/29. Chaukambha Sanskrit Sansthan, Varanasi, India, pp. 134.

7. Byadgi PS (2011) An insight into the understanding of agni and its clinical importance. IJAR, 2(6):1637-1641.

8. Kasha Nath Shastri, Gorakh Nath Chuturvedi (2007) Charak Samhita, Grahanichikitsadhaya 15/3-4. Chaukambha Bharat Academy, Varanasi, India, pp. 453.

9. Byadgi PS (2011) An insight into the understanding of agni and its clinical importance. IJAR, 2(6):1637-1641.

10. Kasha NathShastri, Gorakh Nath Chuturvedi (2007) Charak Samhita, Grahani chikitsadhaya 15/15. Chaukambha Bharat Academy, Varanasi, India, pp. 455.

11. Kasha NathShastri, Gorakh Nath Chuturvedi (2007) Charak Samhita, Grahanichikitsadhaya 15/16. Chaukambha Bharat Academy, Varanasi, India, pp. 465.

12. Kasha Nath Shastri, Gorakh Nath Chuturvedi (2007) Charak Samhita, Grahani chikitsadhaya 15/36-37. Chaukambha Bharat Academy, Varanasi, India, pp. 458.

13. Ambika Dutt Shastri (2007) Susruta Samhita, Annapanavidhiadhaya 46/507-508. Chaukambha Sanskrit Sansthan, Varanasi, India, pp. 223.

14. R. K. Sharma, Bhagwan Dash (2010) Charak Samhita, Trividhkukshiya Vimaniyadhaya 2/9. Chaukambha Sanskrit Series Office, Varanasi, India, pp. 135.

15. P.S. Byadgi (2009) Ayurvediya Vikriti Vigyan and Roga Vigyan, Ajirna. Chaukambha Publication, Varanasi, India, p. 74.

16. Kasha Nath Shastri, Gorakh Nath Chuturvedi (2007) Charak Samhita, Grahanichikitsadhaya 15/45. 
Chaukambha Bharat Academy, Varanasi, India, pp. 460.

17. Yadunandan Upadhaya (2013) Agnimandh Nidanam 6/10-13. Madhava Nidana. Chaukambha Prakshan, Varanasi, India, pp. 229.

18. Ambika Dutt Shastri (2007) Susruta Samhita, Annapanavidhiadhaya 46/511. Chaukambha Sanskrit Sansthan, Varanasi, India, pp. 223.

19. http://www.jainworld.com/preksha/vidyajain/pd11.htm

20. Byadgi PS (2011) An insight into the understanding of agni and its clinical importance. IJAR 2(6): 1637-1641.

21. http://naturalsociety.com/why-drinking-too-muchwater-can-be-hazardous-to-your-health.

22. Sharma Rk, Bhagwan Dash (2010) Charak Samhita, Rasavimaniyadhaya 1/24. Chaukambha Sanskrit Series Office, Varanasi, India, pp. 129.

23. http://www.drlwilson.com/articles/DIGESTION

24. Saini Neera, Pal Pradeep Kumar, Byadgi PS (2015) Role of Virrudh Chesta in the Development of Amavata. STM 4(1): 52-54.

25. http://www.calmclinic.com/anxiety/symptoms/digestiv e-problems

26. http://www.drlwilson.com/articles/DIGESTION

27. SainiNeera, Pal Pradeep Kumar, Byadgi PS (2015) Role of VirrudhAhara in the Genesis of Amavata. AJPHR 3(3): 1-10.

28. http://www.calmclinic.com/anxiety/symptoms/digestiv e-problems

29. http://branchbasics.com/ways-to-increase-stomachacid-production/

30. http://livingwithgastroparesis.com/gastroparesissleep/\&Digestion

31. http://www.ayurvedalive.in/ajirna-indigestion

32. http://www.keralaayurveda.biz/content/good-eatinghabits-ayurveda-says-can-aid-good-digestion

33. Krishna Gopal (2012) Rasa Tantra Sara avum Siddhaproyaga Sangraha, Roganusar Ausaudh Suchi. (21st), Krishna Gopal Ayurveda Bhawan, Kaleda, Ajmer, Rajasthan, India, 2.

\section{Source of Support: Nil \\ Conflict of Interest: None Declared}

How to cite this URL: Nirmala Kushwaha \& Urmila Waxar: Potential Role of Acinull-P In Management Of Ajirna W.S.R To Indigestion. International Ayurvedic Medical Journal \{online\} 2020 \{cited November, 2020\} Available from: http://www.iamj.in/posts/images/upload/5073_5080.pdf 